\title{
DEVELOPMENT OF A DECISION-MAKING ALGORITHM FOR DETERMINATION OF THE OPTIMAL LAND USE FUNCTION
}

\author{
Andrzej Biłozor, Ph.D. \\ Faculty of Geodesy and Land Management \\ University of Warmia and Mazury in Olsztyn \\ e-mail:abilozor@uwm.edu.pl
}

\begin{abstract}
Although the arrangement of urban space use functions is the outcome of the activity of many different entities, it is not a random activity, as there are general principles guiding the creation process of such a structure. The correct selection and arrangement of areas in a city for different types of use is of significant importance for the fulfillment of economic, functional and planning needs of the city. The concept of land division therefore has a decisive effect on the spatial structure of every city.

The growing shortage of free urban space causes, or even forces, its optimal use. The optimization of land use functions in a city aims to verify mismatched land functions and replace them with functions best matched to the present natural and anthropogenic features. Adaptation of problem areas generating "spatial conflicts" should be based on the opinion of the city's residents to reflect their current needs as well as on economic calculations. This paper presents a procedure for determining optimal states of land use as a tool in the urban space management process. The developed algorithm is designed to form the basis for conducting spatial monitoring, serving to analyze and verify individual land management forms in order to minimize the costs of transformation and maximize income.
\end{abstract}

Słowa kluczowe: algorithm, optimization, the functions of urban space, urban space optimization.

JEL Classification: R14.

Citation: Biłozor A., (2013), "Development of a decision-making algorithm for determination of the optimal land use function", Real Estate Management and Valuation, vol. 21, no. 2, pp. 15-24.

DOI: 10.2478/remav-2013-0022.

\section{Introduction}

Spatial management includes all passive and active actions concerning entities and objects related to spatial organization and use (KUCHARSKA-STASIAK 1998). The management of space as a scarce resource consists of maximizing effects with the given spatial resources and minimizing the expenditure of space for achieving the given effects (MEYER 1998). All human actions included in the definition of space management are subordinated to the general rule that man is (usually) guided in his actions by the least effort principle. He tries to achieve the goals of spatial management with the least possible expenditure of effort and resources (MALISZ 1984). This involves making decisions on land allocation for diverse social and economic functions and decisions on the manner in which these areas are to be managed and developed. The results are specific states of management, spatial structures and organization of society, which leads to the planned arrangement of residents, flats and social, technical and economic infrastructures in a given area for its rational management, functioning and use, taking into account environmental protection and living standards (CYMERMAN 2001, 2002).

Literature analysis indicates that land transformation is one of the main tools (instruments) for 
planning space management (spatial management). As an aim and effect of spatial planning, it must optimize the relationships between the natural/economic and the social/ecological value of space. In the field of land management, the notion of optimization is used in the verification of the best (optimal) manners of land use. This verification concerns mostly the problem of optimal spatial location of economic entities and very often refers to areas of cities and their environs (BAJEROWSKI 2003). The optimization method is also called the "land valorization method" and its genesis in Poland is the "Warsaw optimization method" (LEŚNIAK 1985). This method was developed in the years 19611963 as a tool for post-war urban development planning. The objective of the method was the rational location of investments in the city. Minimization of the costs of obtaining land, investments and operating costs were adopted as the main principles. When the possible manners of land use were determined and combinations of individual variants were worked out, the model helped to assess investment and operating costs. The optimization method was used during the preparation of land use plans in the years 1961-1978 for several cities: Warsaw, Gdańsk, Cracow, Łódź, Poznań and Skopje (BRONIEWSKI, SUCHORZEWSKI 1979).

The most often encountered definition of optimal land use is that which results in the highest land value from among the physically possible and legally permitted forms of use, while remaining consistent with its function (KINZY, 1992). The optimal state of land use can be understood as a function of the needs of man and nature, i.e., as the sum of the values of natural and anthropogenic features which results in the highest land value. At the same time, there is a conflict between the necessity to fulfill human needs and the necessity for changes in the manner of use that goes along with changes in environmental conditions and natural possibilities. According to BAJEROWSKI (2003), every state of land use is simultaneously a function of demand for such a manner of space use. Demand causes areas with features appropriate for a given state to be chosen or it becomes compulsory to transform their features to achieve the optimal state of use. For this reason, the state of land use can also be called the land function (BAJEROWSKI 2003). The states of land surface use can be characterized by such features as: the current manner of use, the highest utility value of the land for its use in terms of its internal features, the highest utility value of the land according to its function (BAJEROWSKI 2003, following HOPFER 1981).

The essence of optimization is that every fragment of space has the possibility to obtain an optimal state of use at a given moment. However, the presence of appropriate features in a given fragment of space does not in the least bit "force" the assumption of the correct state of use of the space. It should only be stated that the probability of transforming the current state of use towards the optimal state is highest (maximum). Chance will lead to the real achievement of a given state of use (BAJEROWSKI 2003, after ZUKAV 1995). Optimization of the land use function, especially in urban areas, requires the solution of a number of problems at the stage of reasearch and analyses to minimize the possibility of spatial conflicts arising.

\section{Development of land use function optimization principles}

Land management is a science which has a direct impact on every person's life. This relationship is not one-sided, as man also has a direct impact on the appearance of and manner in which surrounding spaces are used. The arrangement of urban space use functions is the outcome of the activity of different entities, but it is not random. There are general principles guiding the formation process of this structure. The correct selection and arrangement of areas in a city for different types of use is of significant importance for the fulfillment of economic, functional and planning needs of the city. The concept of land division has, therefore, a decisive effect on the spatial structure of every city.

The need for sustainable development is the effect of man's innate will to maintain the natural order of the world, a certain "optimum" which enables the development of mankind and ensures their survival. The optimization of urban space functions aims to identify the most mismatched land functions and propose their replacement with functions best matched to the present natural and anthropogenic features. Adaptation of the problem areas (generating spatial conflicts) should be based on the opinion of the city's residents (reflecting their current needs), which can be referred to as "social optimization," and on economic calculations, which can be called "economic optimization".

Survey-based social optimization requires the construction of a questionnaire and conducting a survey to determine social preferences (for the whole population, e.g., by referendum or public consultation, or for selected individuals from the sample) regarding the management of a given city or part of city (particular district). A survey is an example of a standardized technique for acquiring 
information as a result of mutual communication, in which communication takes place in written form, without interaction with the surveyor. A survey questionnaire should contain information on the manner in which it is to be filled-in as well as on the aim of the research. According to SOŁOMA (2001), a survey allows for:

- obtaining information relatively quickly and cheaply from a large spatially-dispersed population,

- eliminating the influence of the surveyor,

- developing a sense of anonymity among the respondents,

- eliminating surveyor errors,

- obtaining a uniformity of materials.

At the same time, a survey makes it impossible to:

- investigate a broad range of issues in depth because of a limited number of questions and no possibility to ask additional questions while the respondent is providing answers,

- conduct research on $100 \%$ of distributed survey questionnaires,

- always obtain accurate information, as a result of misunderstanding questions or the misinterpretation of instructions on the manner of filling in the form,

- include "control questions", to verify information on key issues raised in earlier questions.

In order to determine the residents' needs and requirements, it must be determined how they perceive the city, what character it should have and which investments should be carried out in the near future. A method of sociological research, which includes surveys, was used to analyze the needs and requirements of the residents of the city of Olsztyn. The questions the respondents were asked to answer concerned:

1. Which role should Olsztyn fulfill?

- Administrative center

- Academic center

- Communications center

- Business center

- Cultural center

- Industrial center

- Centre of recreation and tourism

- Others, (specify) ...

2. Is Olsztyn an attractive city for investments?

3. What is the level of services offered in Olsztyn?

4. What is the condition of recreational/leisure areas in Olsztyn?

5. How should land management be changed to improve the living conditions of the residents:

- Enlarge recreational areas

- Enlarge investment areas in the commune

- Improve learning conditions and the equipment in schools

- Create new places for children and young people to play

- Increase the number, diversity and availability of service outlets

- Improve the condition of roads, pavements and lighting

- Develop lake shores for recreational and tourist purposes

- Develop areas on lakes and the River Łyna within the limits of Olsztyn

- Increase the number of parking spaces in the city

- Establish new green areas

- Create new cycle paths

- Develop housing (new housing estates)

- Build a recreational sports complex

6. What key investments should be carried out in Olsztyn in the nearest future according to the guidelines laid down in the land use plan?

- Construction of a ring road

- Construct Obiegowa St -an extension of Sikorskiego St to Piłsudski Avenue

- Modernization and development of an integrated public transport system

- Construction of a pedestrian subway under Piłsudski Avenue

- Introduction of new additional means of urban transport 
- Construction of a modern playground in Jaroty

- Construction of a new shopping center

- Construction of a fair/expo/conference center

- Construction of a multi-level car park in the city center

- Others (specify) ...?

7. Please indicate the districts in Olsztyn which are least attractive (e.g., neglected, dangerous places in which investments could be undertaken, but are not, etc.)

8. What investments should be carried out in a given district to improve the residents' standard of living?

The results of the conducted survey will provide information on the residents' needs and requirements related to space optimization in Olsztyn. This will enable the development of a method for the social optimization of the current state of urban space use and indicate optimal states of space in the future, along with a simultaneous prediction of changes.

Another method for conducting research among residents is the creation of "mental maps" by the respondents, which are drawn up to identify their social needs and preferences (used in research on the spatial layout of cities). Such research involves the relationships between residents and their physical, architectural environment (with architecture understood here not only as buildings, but also the surrounding space) as well as the urban planning environment, with fragments of the natural environment. The maps are closely connected with the perception of the surrounding environment and can be an important element of research on the spatial layout of cities. They are a form of analysis of the relationships between the housing environment and the residents. They give a picture of their social needs and expectations as to architectural/urban planning solutions and lead to the proper, diversified development and functioning of a city.

Economic optimization can be carried out on two planes - by minimizing the costs of transformation or maximizing income. Minimization of costs consists of the optimal use of natural and anthropogenic features of the analyzed area through the matrix of natural features, leading to the optimal use of the area (BAJEROWSKI 1996), and the matrix of connections of urban space functions with the features of the area (BIŁOZOR, JĘDRZEJOWSKA 2012). The matrix of connections consists of 11 space functions, 13 natural features and 23 anthropogenic features of the area, which also include the present infrastructure. A fragment of the described matrix is presented in Table 1.

Table 1

Matrix of connections of urban space functions (the land use function) with land features and with the present infrastructure

\begin{tabular}{|c|c|c|c|c|c|c|c|c|c|c|c|c|}
\hline No. & Urban space function & $M N$ & $M W$ & $u$ & US & $U C$ & $P$ & $Z P$ & $Z C$ & WS & $K^{*}$ & $I T^{*}$ \\
\hline 1 & Electricity & 8 & 8 & 9 & 8 & 8 & 10 & 0 & 5 & 3 & 4 & 10 \\
\hline 2 & Telephone & 7 & 7 & 6 & 4 & 8 & 7 & -8 & 3 & -7 & 0 & 8 \\
\hline 3 & Waterworks & 9 & 8 & 9 & 7 & 9 & 9 & 3 & 6 & 3 & 2 & 9 \\
\hline 4 & Sewage system & 7 & 8 & 6 & 3 & 5 & 9 & -6 & 1 & 3 & 3 & 8 \\
\hline 5 & Gas & 7 & 8 & 4 & 2 & 4 & 8 & -8 & -2 & 3 & 4 & 9 \\
\hline 6 & Easy access by road & 7 & 7 & 8 & 2 & 6 & 7 & 1 & 5 & 4 & 6 & 4 \\
\hline 7 & Railway & -10 & -10 & -7 & -10 & 6 & 9 & -9 & -5 & -8 & 9 & 9 \\
\hline 8 & Piers, beach & -7 & -7 & -6 & 8 & -9 & -10 & 0 & -10 & 7 & -8 & -8 \\
\hline 9 & Restaurants & 3 & 4 & 7 & 2 & 3 & -7 & 1 & -6 & 1 & 6 & -9 \\
\hline 10 & Swimming pools & -5 & 1 & 4 & 8 & 4 & -3 & -7 & -9 & -7 & -4 & -1 \\
\hline 11 & Multi-family blocks of flats & -7 & 10 & -2 & -6 & 5 & -4 & 2 & -9 & -8 & -3 & -7 \\
\hline 12 & Single-family houses & 10 & -8 & -3 & -3 & -3 & -9 & 5 & -8 & -9 & -6 & -8 \\
\hline 13 & Public buildings & -3 & 1 & 8 & -9 & 2 & -4 & 4 & -7 & -8 & 0 & -5 \\
\hline 14 & Clubs, pubs & -6 & 3 & 7 & 1 & 4 & -4 & -8 & -7 & 3 & 2 & -4 \\
\hline 15 & Historical monuments & -9 & -10 & -7 & -9 & -6 & -5 & 8 & 3 & -6 & -7 & -7 \\
\hline 16 & Neighborhood with same function & 3 & 2 & -8 & -6 & 1 & 8 & -9 & 3 & 2 & -4 & 3 \\
\hline 17 & Access to education & 4 & 5 & 2 & -6 & 1 & -2 & -9 & -7 & -9 & 3 & -1 \\
\hline 18 & Cinemas, theatres, cultural centers & -4 & -3 & 6 & -9 & -5 & -7 & -7 & -6 & -8 & 3 & 1 \\
\hline 19 & Small floor space shops & 4 & 4 & 10 & 3 & -7 & 1 & -4 & 2 & -3 & 4 & -1 \\
\hline 20 & Large format stores & -7 & -5 & 1 & -10 & 10 & 4 & -10 & -6 & -9 & 9 & 5 \\
\hline 21 & Hard-surfaced roads & 6 & 7 & 8 & 2 & 9 & 10 & -3 & 9 & -2 & 10 & 6 \\
\hline 22 & Cemeteries & -10 & -10 & -9 & -10 & -10 & -10 & 2 & 10 & -6 & 4 & -2 \\
\hline 23 & Religious buildings & -1 & 3 & -5 & -3 & -6 & -2 & 4 & 9 & -8 & 4 & -6 \\
\hline
\end{tabular}




\begin{tabular}{|c|c|c|c|c|c|c|c|c|c|c|c|c|}
\hline 24 & Lake shorelines & -6 & -10 & -7 & 10 & -9 & -8 & 7 & -9 & 10 & -7 & -8 \\
\hline 25 & Rivers and streams & -2 & -7 & 1 & 4 & -8 & -4 & 3 & -8 & 10 & -6 & -5 \\
\hline 26 & Canals and ditches & -10 & -10 & -10 & -6 & -4 & 1 & -9 & -1 & 7 & 5 & 4 \\
\hline 27 & Small standing waters & 1 & 1 & -5 & 6 & -8 & -4 & 4 & 1 & 6 & -6 & -7 \\
\hline 28 & Rows of trees & -4 & -3 & -6 & -2 & -1 & -1 & 9 & 7 & 6 & -6 & 1 \\
\hline 29 & Groups of trees, groves & 1 & -6 & -9 & 6 & -3 & -1 & 7 & 3 & 6 & -8 & -1 \\
\hline 30 & Single trees & -2 & -3 & -3 & 4 & -1 & 0 & 9 & 7 & 6 & -6 & 3 \\
\hline 31 & Bush belts, hedges & 3 & 3 & 5 & -2 & -1 & 0 & 10 & 7 & 6 & 3 & 2 \\
\hline 32 & Observation decks & -7 & -8 & -3 & 9 & -8 & -5 & 7 & 0 & 4 & -7 & -7 \\
\hline 33 & Southern exposure & 5 & 4 & -3 & 6 & -5 & -5 & 6 & 3 & 3 & -10 & -8 \\
\hline 34 & Western exposure & 3 & 2 & -4 & 5 & -6 & -5 & 3 & 3 & 3 & -10 & -4 \\
\hline 35 & No land slope & 6 & 3 & -3 & -6 & 10 & 10 & -3 & 6 & -2 & 9 & 9 \\
\hline 36 & Small land slope & 6 & 1 & 6 & -3 & 5 & 7 & 5 & 7 & 4 & 8 & 8 \\
\hline \multicolumn{2}{|c|}{ Sum of positive points } & 100 & 100 & 100 & 100 & 100 & 100 & 100 & 100 & 100 & 100 & 100 \\
\hline \multicolumn{2}{|c|}{ Sum of negative points } & -100 & -100 & -100 & -100 & -100 & -100 & -100 & -100 & -100 & -100 & -100 \\
\hline \multicolumn{2}{|c|}{ Sum total } & 0 & 0 & 0 & 0 & 0 & 0 & 0 & 0 & 0 & 0 & 0 \\
\hline
\end{tabular}

Source: BIŁOZOR, JĘDRZEJOWSKA 2012.

Functions are optimized by the identification of land features present in the studied area and the probability of a given land use function occurring is determined on this basis. The sum obtained from the matrix columns specifies the value of the probability and a negative sign of the sum means a probability equal to zero. The function from the matrix which obtains the highest probability is the optimal function for the studied area. This function uses the maximum potential of the area, i.e., all features which positively influence its selection, along with the simultaneous minimization of costs.

Maximization of income from land use transformation can be based on the principles of the game theory, which is known as the theory of making decisions under interactive conditions, or the mathematical theory of conflict situations. The game theory is a part of a decision-making theory and its characteristic features are a mathematical apparatus used for making decisions in a situation of conflict. It analyzes the possible behaviors of conflict participants and makes the optimal decisions under the given conditions. It does not examine the causes or genesis of conflicts because it is interested only in optimal solutions.

The profitability of a transformation is the difference between the value of the area for a given land function and the costs of transformation to this function (BAJEROWSKI 1996). For such a conversion to make sense, the future value of the new (optimal) state of use must be higher than the value of the current state of use. The transaction price index (i.e., the land value obtained from a computer simulation of the real estate property sale by tender), which is a modification of the formula for the expected game value, can be used to determine the comparative unit for different states of land use (OGRYZEK 2007 after KAMIŃSKA 2006).

where:

$$
W k=\left(C_{T 1}, C_{T 2}, p_{1}, p_{2}\right)=p_{1} C_{T 1}+p_{2} C_{T 2}
$$

where:

$$
C_{T}=J+C_{w}
$$

where:

$C_{T 1}$ and $C_{T 2}$ - transaction prices,

$\mathrm{p}_{1}, \mathrm{p}_{2} \quad$ - probability of the transaction price occurring,

Wk - price index,

$C_{w} \quad$ - reserve price,

J - increment unit.

Game variances should be computed for a more precise measure of risk. The higher the deviation from the results, the riskier the game. The program selects the price index with the lowest risk obtained from a modification of the formula for game variances (OGRYZEK 2007 after KAMIŃSKA 2006).

The value of an area for all functions is determined as the most probable price of the real estate property sale by tender. The comparison of indices for all land functions determines the potential profits from the real estate property sale by tender for each manner of use. In this way, it is possible to establish predicted model comparative units for all land functions (OGRYZEK 2007).

Using linear programming and the mathematical notation of optimizing conditions for the land 
function, it can be determined whether a given area can be subjected to the transformation process while meeting two basic conditions:

- the sum of natural and anthropogenic values for the given function is higher than the natural and anthropogenic values of the current function;

- the economic value after the transformation is highest compared to the current one and relative to the other land functions.

If these basic conditions for the optimality of the land function are not met, the highest sum of natural, anthropogenic and economic values after the transformation of the land should be assumed as its solution.

\section{Development of a decision-making algorithm for determining the optimal land use function}

Every fragment of space has, or has the capacity to achieve, the optimal state of use at a given moment. However, every change in the manner of use of the analyzed area should be preceded by determining the profitability of this transformation. It may turn out that the difference between the value of an area with future optimal use and the value of current use are lower than the costs of the transformation. The analysis and interpretation of social, spatial and economic information is the basis for implementing the process of space planning optimization as a tool facilitating the comprehension of mutual relationships occurring between all objects within the planning space in the scope of both land management and economics, finance, management and demography.

The developed algorithm is a part of a system supporting the land management decision-making process. The decision is, in this case, the effect of an exchange of information between different entities who contribute new arguments and preferences to the decision-making process, both from the social and economic points of view. Generally, the following stages of the decision-making process can be assumed (KNOSALA 2005; SZAPIRO 2000, WIŚNIEWSKI 2008, ZIELIŃSKI 2000): definition of the decisionmaking problem, a system of goals, decision-making alternatives, decision-making limitations, the selection of the decision and then its execution and control. The land use-function-change algorithm, as a space planning optimization instrument, will, in this case, be an element facilitating the making of the correct /optimal decision on the use of the analyzed area. This is an ordered set of operations which can be used to obtain a solution to a specific problem, i.e., the determination of the optimal land use function. The modified decision-making algorithm, adapted to the specificity of land management, is presented and described in detail below.

The procedure for conducting the decision-making process for the selection of the optimal land use function should be carried out in the following stages:

1. spatial monitoring - the selection of an area where the change of function is possible or necessary (this mostly concerns functions with a "non-urban" character, i.e., agricultural land, orchards, allotment gardens, natural/non-cultivated green areas, etc.)

2. setting the principles of social optimization - the development of principles and manners of conducting surveys or mental maps concerning the state of space management and interpretation of the obtained results,

3. determination of economic conditions for the optimality of the land function - an analysis of the land transformation process in regard to functionality, costs and profits,

4. development of the principles of economic cost optimization,

4.1 identification of anthropogenic and natural space features indicating the current state of land development,

4.2 conducting an analysis of geoinformation necessary in the spatial optimization process,

4.3 determination of the natural, anthropogenic and social value for each land function using the developed matrix of features producing optimal land use,

5. development of principles of economic income optimization,

5.1 analysis of real estate property transaction prices from the local real estate property market,

5.2 conducting a simulation of the real estate property sale by tender,

5.3 identification and analysis of the effect of elements of economic calculations in land transformation,

6. analysis of the social and economic circumstances of the studied area,

7. optimization of the land use function.

The spatial use optimization procedure aims to minimize uncertainty in the spatial planning process. The proposed system can be used on different scales and with diverse degrees of detail of 
spatial analyses as well as with so-called "spatial monitoring" to analyze and verify individual land management forms with regard to minimizing the costs of transformation and maximizing income.

\section{Decision-making process in the determination of the optimal land use function - verification of the developed procedure}

A detailed verification of the developed procedure was conducted for a selected part of Olsztyn - the Pieczewo housing estate.

The survey was conducted among 50 respondents, all of whom were residents of Olsztyn, and found that:

1. $90 \%$ of the respondents believe that Olsztyn should be a center of recreation and tourism, $10 \%$ would like Olsztyn to be an academic center,

2. $90 \%$ of the respondents consider Olsztyn to be a city characterized by a medium attractiveness for investments,

3. $80 \%$ consider the range of offered services satisfactory,

4. all the respondents characterized the condition of recreational/tourist areas in the city as good,

5. investments related to the road infrastructure (improving the condition of roads and the number of parking spaces), construction of new cycle paths, investments in housing and the construction of tourism and sports/recreational facilities were particularly important for the respondents,

6. the most important investment concerning the city's spatial policy is the construction of a ring road

7. the least attractive housing estates are Zatorze, Pieczewo,Pojezierze and Kętrzyńskiego.

A particularly neglected and at the same time least attractive place in Pieczewo is a former military area located in the south-eastern part of the housing estate. There is also no possibility of unrestricted and safe bicycle traffic and the number of parking spaces in the housing estate is insufficient. The optimal manner of land development is the expansion of single- and multi-family housing. The number, diversity and availability of service outlets, as well as sports and recreation facilities should be increased. It is also necessary to develop green areas together with a cycle path system. Additionally, it is important to increase the number of parking spaces in the housing estate and improve the condition of the streets, sidewalks and lighting.

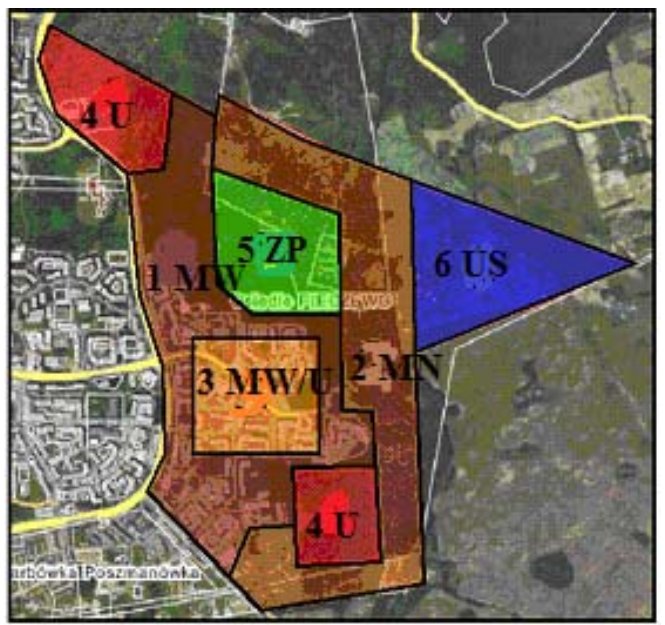

Fig. 1. Optimal space management functions in the Pieczewo housing estate. Source: Own work.

For the needs of the conducted analysis, six functional zones with determined optimal uses were designated in the Pieczewo housing estate on the basis of data obtained in the survey process and following a detailed analysis of entries in planning documents:

- zone 1 (1 MW) - housing areas with the domination of multi-family housing,

- zone 2 (2 MN) - housing areas with the domination of single-family housing,

- zone 3 (3 MW/U) - housing and service areas,

- zone $4(4 \mathrm{U})$ - areas of large format trade services,

- zone $5(5 \mathrm{ZP})$ - cultivated green areas,

- zone 6 (6 US) - sports and recreation areas. 
The possibility of optimizing a selected area with regard to minimizing costs as well as anthropogenic and natural space features were analyzed and the optimal manner of its use was determined. An example of the procedure is presented in Fig. 2. Table 2 contains an inventory of spatial features for a selected fragment of the analyzed space - the square marked with number 17 , for which the optimal function is single-family housing.
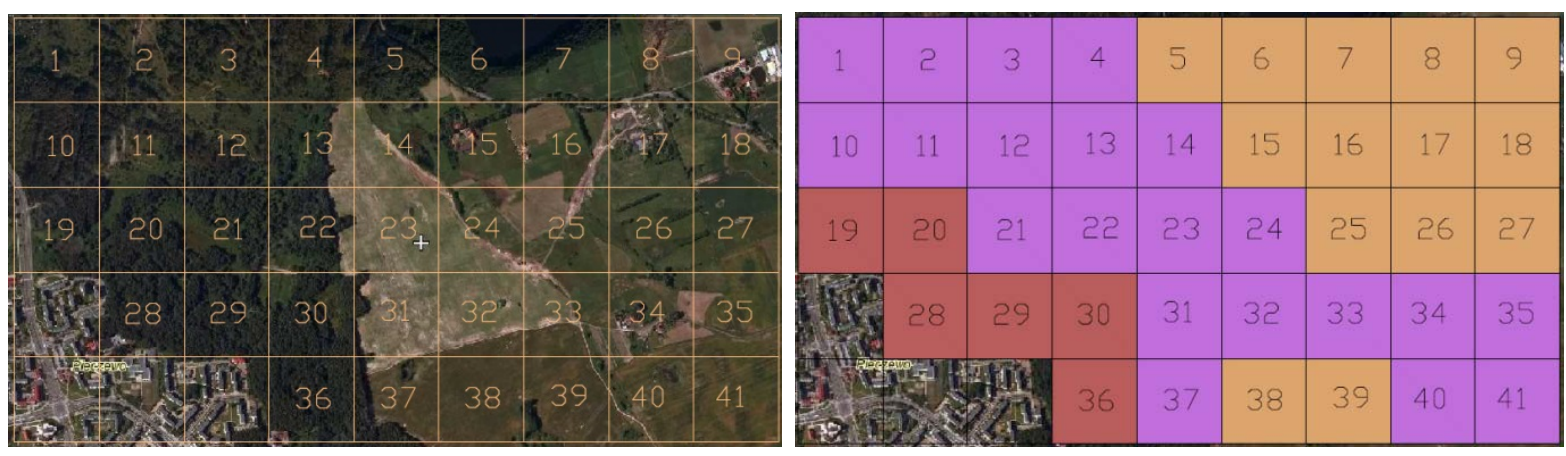

Fig. 2. Optimal space management functions in the Pieczewo housing estate. Source: Own work.

Table 2

Matrix of connections of urban space functions (the land use function) with land features and with the infrastructure present for square 17

\begin{tabular}{|c|c|c|c|c|c|c|c|c|c|c|c|}
\hline $\begin{array}{l}\text { Inventory - square } 17 \\
\text { Features within the area: }\end{array}$ & $M N$ & MW & $u$ & US & UC & $P$ & $Z P$ & $\mathrm{ZC}$ & WS & $K^{*}$ & $I T^{*}$ \\
\hline Electricity & 8 & 8 & 9 & 8 & 8 & 10 & 0 & 5 & 3 & 4 & 10 \\
\hline Telephone & 7 & 7 & 6 & 4 & 8 & 7 & -8 & 3 & -7 & 0 & 8 \\
\hline Waterworks & 9 & 8 & 9 & 7 & 9 & 9 & 3 & 6 & 3 & 2 & 9 \\
\hline Sewage system & 7 & 8 & 6 & 3 & 5 & 9 & -6 & 1 & 3 & 3 & 8 \\
\hline$\overline{\text { Gas }}$ & 7 & 8 & 2 & 2 & 4 & 8 & -8 & -2 & 3 & 4 & 9 \\
\hline Groups of trees, grove & 1 & -6 & -9 & 6 & -3 & -1 & 7 & 3 & 6 & -8 & -1 \\
\hline Small land slope & 6 & 1 & 6 & -3 & 5 & 7 & 5 & 7 & 4 & 8 & 8 \\
\hline Sum & 45 & 34 & 29 & 27 & 36 & 49 & -7 & 23 & 15 & 13 & 51 \\
\hline \multicolumn{12}{|l|}{ Features in the vicinity of the area: } \\
\hline Easy access by road & 7 & 7 & 7 & 2 & 6 & 7 & 1 & 5 & 4 & 6 & 4 \\
\hline Multi-family blocks of flats & -7 & 10 & -2 & -6 & 5 & -4 & 2 & -9 & -8 & -3 & -7 \\
\hline Public buildings & -3 & 1 & 7 & -9 & 2 & -4 & 4 & -7 & -8 & 0 & -5 \\
\hline Neighborhood with same function & 3 & 2 & -8 & -2 & 1 & 8 & -9 & 3 & 2 & -4 & 3 \\
\hline Access to education & 4 & 5 & 2 & -6 & 1 & -2 & -9 & -7 & -9 & 3 & -1 \\
\hline Small shops & 4 & 4 & 10 & 3 & -7 & 1 & -4 & 2 & -3 & 4 & -1 \\
\hline Hard-surfaced roads & 6 & 7 & 8 & 2 & 9 & 10 & -3 & 9 & -2 & 10 & 6 \\
\hline Sum & 14 & 36 & 24 & -16 & 17 & 16 & -18 & -4 & -24 & 16 & -1 \\
\hline Total & 59 & 70 & 53 & 11 & 53 & 65 & -25 & 19 & -9 & 29 & 50 \\
\hline
\end{tabular}

Source: Own work.

The conducted income optimization, i.e., analysis of real estate property transaction prices from the local real estate property market and simulation of real estate property sale by tender indicate that it would be best to allocate the analyzed area to multi- and single-family housing. The analysis of results obtained in the social and economic optimization process indicates that the optimal land use function for most of the analyzed area is single- and multi-family housing. Maximum possible income from the transformation of the land was obtained by subtracting the forecasted transaction price and the price for the current land use. The forecasted transaction price was generated by the simulator. When determining the profits of a transformation process, the cost of the process and risk of simulator error are taken into account. Minimum costs are provided for the single and multi-family residential function because of such records in the operative study of land use conditions and the local plan of land development for the area.

Correct urban space management requires conducting continuous research on the optimal manners of land development with regard to both social expectations and economic aspects. Optimal states of space can be determined by analyzing the manner of development of areas designated in the 
process of spatial monitoring, i.e., the qualitative and quantitative observation of problem areas (conflict areas, "non-urban" areas). Social optimization will indicate the directions for shaping spatial policy, both on the scale of the whole city and in a particular district or part of a district. Economic optimization will indicate how best to take advantage of the natural and anthropogenic values of space and the current situation on the real estate property market. All information collected in the optimization process should become a tool in the creation of a rational and optimal spatial management policy.

\section{Conclusions}

Each city, organizing itself according to the laws of a complex system with mutual connections and relationships, cannot remain in an unchanging state. It undergoes a process of constant transformation and its elements and the relationships between them experience changes. The development of a city is a continuous process and there is no "target state" for which the city should strive. Every attained state is a transitional state and the basis for the next stage. For the spatial development of a city, every change is connected with the erection of a new building (structure or facility) or with the development of a part of an area.

The developed decision-making algorithm will help to determine the optimal land use function with clearly-defined actions necessary to perform the planned task. Social optimization will show which forms of land development demand are highest at a given time. Economic optimization will determine the introduction of which form is most justified from an economic point of view. The use of the developed sale by tender simulator for planning purposes, as one of many possible tools to support economic optimization, and the matrix of features determining the optimal states of use enables the establishment of (and controlling predicted model comparative units for) all land functions and will determine the conditions for the optimality of the land function. The developed tool for selecting the optimal function can be useful in the process of developing spatial use plans. It helps to select solutions most advantageous for a given area, taking into account not only economic factors but also ecological aspects and human needs. Properly collected and interpreted geoinformation may provide the basis for efficient spatial management, the main instrument of which is the land use transformation measurement.

\section{References}

BAJEROWSKI T., 1996, Metodyka wyboru optymalnego użytkowania ziemi na obszarach wiejskich, Acta Acad. Agricult. Tech. Tech. Olsz. Geoadaesia et Ruris Regulatio, No 26, Supplementum B.

Bajerowski T. BAL A., BiŁOzor A., Gerus-GościewsKa M., Sidor I., SZureK M., TuRKowsKa O., WIELGOSZ A., 2003, Podstawy teoretyczne gospodarki przestrzennej $i$ zarzadzania przestrzenia, UWM Olsztyn.

BiŁOZOR., JĘDRZEJOWSKA K., 2012, Optymalizacja przestrzeni miejskiej - studium na przykładzie miasta Olsztyn, Studia i Materiały Towarzystwa Naukowego Nieruchomości, vol. 20, nr 2.

BRONIEWSKI S., SUCHORZEWSKI W., 1979, Metoda optymalizacji warszawskiej, W: Kulikowski R., Owsiński J. W. (red.), Zastosowanie analizy systemowej w modelowaniu rozwoju regionalnego, PWN, Warszawa Łódź, s. 91-102.

Cymerman R., Grabowski R., GWiá́dZińsKa M., PieKARSKA B., ZAWAdZKa J., 2001, Planowanie $i$ zagospodarowanie przestrzenne $w$ gospodarce nieruchomościami (wycena, zarzadzanie $i$ pośrednictwo $w$ obrocie), Materiały edukacyjne N - 9. Wydawnictwo Educaterra, Olsztyn.

CYMERMAN R., GRZĄDKA B., TYSZKO L., 2002, Gospodarka przestrzenna jako dziedzina wiedzy i praktyki ksztattujaca ład przestrzenny, ACTA SCIENTIARUM POLONORUM, Administratio Locorum 1 (12), Wydawnictwo UWM, Olsztyn.

KAMIEŃSKA T., 2006, <http://ekonom.univ.gda.pl/mikro/skladosobowy/Kaminska/SD/ Teoria\%20ry-zyka_popr1.pdf>.

KINZY S.A., 1992, Dwelling attribute forecasts based on land residua maximization, Land Economics, 68(4): s. 380-396.

KNOSALA E., 2005, Zarys nauki administracji, Kantor wydawniczy, Zakamycze.

KUCHARSKA-STASIAK E., 1998, Leksykon rzeczoznawcy majątkowego, Polska Federacja Stowarzyszeń Rzeczoznawców Majątkowych, Warszawa.

LEŚNIAK J., 1985, Planowanie przestrzenne, Państwowe Wydawnictwo Naukowe, Warszawa. 
MALISZ B., 1984, Podstawy gospodarki i polityki przestrzennej, Wydawnictwo Polskiej Akademii Nauk, Wrocław - Warszawa - Kraków - Gdański - Łódź.

MAYER B., 1998, Gospodarka przestrzenna - mechanizmy rozwoju, teorie i systemy, Polskie Towarzystwo Ekonomiczne, Szczecin.

OGRYZEK M., 2007, Weryfikacja metodyki wyboru optymalnego użytkowania ziemi wg Bajerowskiego dla potrzeb zarzadzania przestrzenia planistyczna, Acta Sci. Pol., Administratio Locorum 6(2) 2007, 19-34.

SoŁOMA L., 2002, Metody i techniki badań socjologicznych: wybrane zagadnienia, Wydawnictwo Uniwersytetu Warmińsko-Mazurskiego, Olsztyn.

SZAPIRO T., 2000, Decyzje menedżerskie z Excelem, Polskie Wydawnictwo Ekonomiczne, Warszawa.

WIŚNIEWSKI R. i in., 2008, Gospodarowanie gminnymi zasobami nieruchomości, Wydawnictwo UWM w Olsztynie.

ZIELIŃSKI J., 2000, Inteligentne systemy w zarządzaniu. Teoria i praktyka. Wydawnictwo Naukowe PWN, Warszawa. 